\title{
Discussion on the Teaching Development of Thai Courses in Universities
}

\author{
Chunli Cai* \\ Dehong Teachers' College, Mangshi 678400, Yunnan Province, China \\ *Corresponding author: Chunli Cai, 2182783340@qq.com
}

\begin{abstract}
In recent years, with the expansion and extension of China's free trade platform, construction has gradually developed toward Southeast Asia and South Asia, thus resulting in the phenomena whereby Thai language courses have become more common and more universities have begun to cultivate Thai language majors. In this process, improving the effectiveness of Thai courses has become the key; therefore, schools and Thai language teachers should pay attention to this. In order to achieve the language teaching goal put forward by the Ministry of Education, it is necessary to accelerate the development of Thai courses in universities and explore a new development path for them, so that the teaching quality of Thai courses can be guaranteed. Based on this, this paper mainly discusses the development history of the curriculum of Thai language courses in universities.
\end{abstract}

Keywords: Thai language course; University; Curriculum; Teaching; Development

Publication date: December 2021; Online publication: December 27, 2021

\section{Introduction}

In the era of globalization, the ASEAN-China Free Trade Area has achieved rapid development, thus narrowing the relationship between China and Thailand. This in turn increases the social demand for Thai talents, leading to more Thai courses being offered by universities and courses where Thai is assumed as a second language, in order to promote multilingual teaching. In order to ensure that non-Thai students would be able to master this language from scratch, the quality of the curriculum should be improved and the teaching mode, teaching methods, as well as teaching system should be modified, so as to realize the output of talents batch by producing batch after batch of Thai talents.

\section{Development trend of the curriculum of Thai language courses in universities}

According to incomplete statistics and taking Yunnan Province as an example, the number of students majoring in minority languages in the province is about 50,000. Local documents and meeting requirements have clearly pointed out that in three years, the number of talents trained in minority languages should be increased to about 100,000. As of 2015, there were more than 10 undergraduate universities offering Thai language courses in Yunnan Province, with 1,900 students enrolled; however, the fundamental goal has not been achieved in regard to the specific educational scale ${ }^{[1]}$. It can be seen that the vast majority of schools in Yunnan Province with their main training direction for tourism, business, Thai language and literature, machinery, construction, agriculture, as well as medicine attach great importance to the cultivation of compound Thai talents, but the lack of such talents leads to a phenomenon whereby the talent training goals and expected social development goals are out of reach. Hence, it is of practical significance to strengthen the research on Thai language courses offered by universities and improve the effectiveness of their curriculum. 


\section{Problems existing in the curriculum of Thai language courses offered by universities}

\subsection{Non-standardized purpose of teaching}

Thai courses are similar to the English courses offered by universities, but because most students are only exposed to Thai after stepping into universities, the teaching requirements should not be too complex and far from consistent with the teaching requirements of English courses. The Ministry of Education has issued strict requirements for English courses offered by universities in terms of listening, reading comprehension, oral, and translation, but the requirements for Thai courses are not clear as of now, resulting in the lack of learning goals among elective students. In that case, these courses assume a single pattern and their teaching effects are not up to par.

\subsection{Unreasonably poor course allocation}

At present, although the curriculum of Thai courses offered by universities is constantly improving, the number of hours are gradually decreasing because students' are not fond of the curriculum. This directly affects the teaching effect and the preference of most students in choosing this course.

\subsection{Learning problems among students}

First of all, for each and every student, there are different expectations in learning; therefore, the learning enthusiasm of each student is different from the other. For example, students from the College of Humanities and International Studies would learn in Thai after reaching a certain stage ${ }^{[2]}$. As many students have zero-basic learning, the teaching effect and learning effect are affected by the students' learning attitude. Many students in the first and second semester possess a relatively good learning attitude, but after the third and fourth semester, it declines due to various factors, thus their learning enthusiasm is affected.

\section{Development history of Thai language courses in universities}

Taking a university in Yunnan Province as an example, this article explores the development history of the curriculum of the Thai language course offered by the university.

\subsection{Exploring the practice of the Thai language course in the university}

First of all, the course selection mode was launched. In October 2010, in order to fully implement the plan of cultivating minority language talents in Yunnan Province, the university chose to offer Thai courses for undergraduate students in sports, music, and arts major, making it as a compulsory course. The credits obtained from the course replaced those of English. In 2010, 115 students took the course, and they learnt during class hours; thus, they did not have to spend their weekends or free time learning the language. In 2011, Thai courses were offered to Central African English students. In that year, all the students from 17 schools were willing to choose Thai. The final statistics showed that the total number of applicants was 38 . As the elective students were scattered, in order to prevent conflicts, the time was changed to night classes. In 2012, there were 17 Thai students in elective universities. At this time, Thai classes were offered. However, due to lack of teachers at that time, the time of the course was arranged by the teachers. As the course schedule could not be unified at that time, in 2013, the school arranged the course to be held during the weekends. Finally, after years of development, the mode of the course still falls under the main form of the Thai course teaching. Taking into consideration of class schedules, gradually offering a network course has changed the previous time limit and space limit issues faced by the course, thus encouraging more students to choose the course ${ }^{[3]}$. 


\subsection{Exploring the teaching mode of the Thai language course in the university}

From the perspective of the teaching mode, it has gone through three development stages. First, the implementation stage according to previous experience. In this stage, the teaching is conducted based on the English course, in which the course is divided into writing, listening, and speaking. In regard to the new curriculum reform, the teaching mode of the English course has changed, in which independent learning is regarded as a new direction of learning. In this environment, the Thai teaching model cannot continue to mirror the former but to explore a new path in order to ensure a more efficient and accurate teaching process. The Thai curriculum is taught as a comprehensive curriculum, focusing on the teaching forms of in-court practice and content telling. Second, the course consolidation phase. Many students who take Thai courses only have basic knowledge about the language before learning, so students learn from simple knowledge contents, such as syllable spelling, letter recognition, etc. During the second year, students would achieve a certain competency where they would be able to take part in dialogues, gradually achieve independent learning, and skillfully apply the language. Some students lack interest in Thai because it is difficult to choose English content. The school should adjust the teaching goals in such a way to understand the characteristics of vocabulary formation and Thai spelling, so that students can improve their self-directed learning skills ${ }^{[4]}$. Third, the course performance has been improved. As mentioned above, some students are not interested in learning the language, but they assume the course as an elective course. Taking into consideration of the difficulty in learning, it would be expected that they would be unable to follow the pace of learning, thus leading to absenteeism in the later stage. Therefore, when setting the curriculum, it is essential to choose contents that students are interested in and ensure that the knowledge-difficulty levels are calibrated step by step.

\section{Conclusion}

In conclusion, the promotion of China-Thailand relations has made the Thai language valued by schools. As a result, the number of students learning the language has also increased. The Thai courses offered by universities are in continuous exploration and development. There are still some defects in the actual teaching; hence, the reform and innovation of these courses are urgent and can be said to be imperative. In regard to this, the development path of their curriculum has been discussed based on the current development situation, in order to improve the quality of the curriculum and the teaching efficiency.

\section{Disclosure statement}

The author declares that there is no conflict of interest.

\section{References}

[1] Li C, 2019, Takes Chengdu College of Sichuan Foreign Studies University as an Example. Northern Literature (China), 2019(6): 152-153.

[2] Shi S, 2020, Application of Micro-Course Based Hybrid Teaching Model in Thai Speech Course. Journal of Jiangxi Electric Power Vocational and Technical College, 33(10): 36-37.

[3] Duan L, 2020, Thai Curriculum Design in "Thai" at Professional + University. Comparative Research on Cultural Innovation, 4(25): 82-84.

[4] Jiang Q, 2020, Discussion on the Reform and Innovation of Ideological and Political Construction of Thai Reading in Universities. Sino-Foreign Exchanges, 27(27): 40. 